\title{
Pensonomonoor
}

2014, vol. 72, 85-92

http://dx.doi.org/10.12657/denbio.072.007

\author{
Anna Źróbek-Sokolnik, Piotr Dynowski, Czesław Hołdyński
}

\section{In vitro callus and shoot organogenesis from leaf and stem explants of Chamaedaphne calyculata}

\author{
Received: 30 September 2013; Accepted: 25 February 2014
}

\begin{abstract}
Leatherleaf Chamaedaphne calyculata (L) Moench is a relict, rare and endangered species in Poland. There are no reports on the micropropagation of Chamaedaphne calyculata in the literature. Therefore, the aim of this study was to propose a propagation protocol for leatherleaf via indirect organogenesis using leaves and stems (internodal segments) derived from mature plants growing in a natural stand and from plants grown in vitro as explants. The medium developed by Anthony et al. (2004) with 100\%, 50\% and $25 \%$ salt concentrations, supplemented with IAA (5 and $10 \mu \mathrm{M})$ and TDZ (5 and $10 \mu \mathrm{M})$, was used for callus development and the induction of adventitious shoots. The media developed by Anthony et al. (2004) and Anderson (1980), both containing $10 \mu \mathrm{M}$ TDZ and $5 \mu \mathrm{M}$ IAA or $2.28 \mu \mathrm{M}$ zeatin, were used for adventitious shoot elongation. Secondary explants proved to be the most effective starting material for callus induction, the regeneration and elongation of adventitious shoots. The most supportive medium for callus induction and growth and the induction of adventitious shoots was the full medium proposed by Anthony et al. (2004) containing $5 \mu \mathrm{M}$ IAA and $10 \mu \mathrm{M}$ TDZ. Anderson's (1980) medium containing $2.28 \mu \mathrm{M}$ zeatin delivered optimal results in the elongation of adventitious shoots of Ch. calyculata. Roots were cultivated on Anderson's (1980) phytohormone-free medium. Approximately 65\% of the plantlets survived after transfer to the sphagnum-peat and perlite mixture $(3: 1)$. The plants grew normally without any signs of morphological variation. This study makes the first ever attempt to propose an effective micropropagation protocol for Ch. calyculata.
\end{abstract}

Additional key words: heath family (Ericaceae), micropropagation, plant species conservation

Addresses: A. Źróbek-Sokolnik, P. Dynowski, Cz. Hołdyński, Department of Botany and Nature Protection, University of Warmia and Mazury in Olsztyn, Plac Łódzki 1, 10-727 Olsztyn, Poland, e-mail: a.zrobeksokolnik@uwm.edu.pl

\section{Introduction}

Chamaedaphne calyculata (L.) Moench (the only representative of the genus Chamaedaphne) is one of the rarest species of the family Ericaceae in Poland. It is a relic postglacial species characteristic of the boreal climate zone. The global distribution of the species covers the boreal and subarctic zones of Eu- rope, Asia and North America. In Europe and Asia, it is widespread in Siberia and Scandinavia. Poland marks the south-western boundary of the species' European range, and the plant is encountered mostly in lakelands and the Masovian-Podlachian Lowland in marshy forests and peatlands. Nine out of 13 historical leatherleaf localities have survived to this day, and they are seriously threatened by human activity, mainly peatland drainage (Kruszelnicki 2001). Ch. 
calyculata is a native wildlife species in Poland, and it receives full legal protection. It is also a medicinal plant - the Native Americans used poultices of $\mathrm{Ch}$. calyculata leaves to treat inflammations and leaf infusions to reduce fever (Moerman 1998). Ch. calyculata leaf extracts contain flavonoid substances (Shelyuto and Glyzin 1975). Leatherleaf is also a valued ornamental shrub. Chamaedaphne calyculata is endangered by industrial development, environmental pollution and climate change. Optimal conditions for the growth of the species have to be determined to effectively conserve this genetic resource and improve propagation methods applicable to this valuable medicinal and horticultural plant. The micropropagation of Rhododendron sp. and Vaccinium sp. has been discussed extensively in the existing body of literature, but only one report describes ex situ propagation of Ch. calyculata (Malinowska et al. 2004). Further work is needed to determine whether Ch. calyculata can be propagated for the needs of metaplantation or ex situ protection. The development of a highly effective micropropagation method supporting the production of a large number of seedlings over a short period of time would significantly contribute to the preservation of the species in the natural habitat. The proposed method would also contribute to the colonization of well-preserved raised bogs that offer an ideal habitat for this endangered species.

This study proposes a new micropropagation protocol for Ch. calyculata where stem and leaf explants are used as starting material. The discussed experiment is part of a series of investigations dedicated to leatherleaf organogenesis. It explores the effect that explants and culture media have on callus induction and indirect organogenesis. Our findings could have significant implications for the management of Ch. calyculata in rehabilitation and conservation programs. This study is the first ever report on the regeneration of Chamaedaphne calyculata via indirect shoot organogenesis.

\section{Materials and methods}

\section{Plant material and explant preparation}

The experimental material was collected from mature Ch. calyculata plants grown naturally (marked as primary explants) and plants grown in vitro (marked as secondary explants). $5-10 \mathrm{~cm}$ sections of young, one-year shoots were sampled from selected mature plants growing in the Masurian Landscape Park (NE Poland). Prior to surface sterilization, shoot fragments were washed for 1 hour under running water with the addition of several detergent drops (Tween $20)$. The shoots were soaked in $70 \%$ ethanol solution $(\mathrm{v} / \mathrm{v})$ for $60 \mathrm{~s}, 10 \%$ chloramine B solution (w/v) for $15 \mathrm{~min}$ and rinsed three times for $5 \mathrm{~min}$ in sterile deionized water. Aseptic shoot sections of 5-10 cm were obtained from a plantlet culture grown on a phytohormone-free WPM medium (Lloyd and McCown 1980). In the experiment, entire leaves and internodal stem segments were applied as explant material. The axenic leaves of plants or plantlets were wounded by three to four transverse cuts across the leaf blade on the abaxial surface to remove the petioles and leaf tips (marked as PE-L for primary explants and SE-L for secondary explants). Explants measuring approximately $1 \mathrm{~cm}$ in length were excised from axenic stems after decapitation and after the removal of tissue that had turned brown under the influence of the sterilizing agent (marked as PE-S for primary explants and SE-S for secondary explants). All stem explants were arranged horizontally on the surface of the respective medium. The abaxial surface of leaves was in contact with the medium.

\section{Induction and development of calluses and adventitious shoots}

The study was conducted in two stages.

Preliminary experiments were carried out to determine the optimal TDZ and IAA combinations for further experiments. A basal medium (BM) (Anthony et al. 2004) containing full strength Gamborg's B5 (Gamborg et al. 1968) salts, supplemented with $10 \mathrm{mg} \mathrm{l}^{-1}$ thiamine- $\mathrm{HCl}, 5 \mathrm{mg} \mathrm{l}^{-1}$ pyridoxine- $\mathrm{HCl}$, $5 \mathrm{mg}^{-1}$ nicotinic acid, $3 \%$ sucrose and $0.7 \%$ agar, was used as control. The basal medium (BM) was supplemented with TDZ at $0 \mu \mathrm{M}, 5 \mu \mathrm{M}$ and $10 \mu \mathrm{M}$ and IAA at $0 \mu \mathrm{M}, 5 \mu \mathrm{M}$ and $10 \mu \mathrm{M}$. pH was determined at 5.0. Only secondary explants (isolated from plantlets grown in vitro) were used in the experiment.

The effect of mineral salt concentrations on the induction and development of the callus and adventitious shoots for different explants was examined in subsequent experiments. Primary (isolated from naturally grown plants) and secondary (isolated from plantlets grown in vitro) explants were placed on a basal medium (BM) whose composition was identical to that described in the previous experiment, and on media whose salt content was reduced to $50 \%(1 / 2$ $\mathrm{BM})$ and $25 \%(1 / 4 \mathrm{BM})$ relative to $\mathrm{BM}$. All media were supplemented with $10 \mu \mathrm{M}$ TDZ and $5 \mu \mathrm{M}$ IAA. pH was determined at 5.0.

\section{Elongation of adventitious shoots}

Fragments of callus clumps (developed on secondary explants) with five adventitious shoots were transferred onto the elongation medium. Two variants of the BM medium, containing $10 \mu \mathrm{M} \mathrm{TDZ}$ and $5 \mu \mathrm{M}$ IAA (BM-A) or $2.28 \mu \mathrm{M}$ zeatin (BM-B), and two variants of Anderson's medium (1980) supplement- 
ed with $3 \%$ sucrose, $0.7 \%$ agar, $10 \mu \mathrm{M}$ TDZ and $5 \mu \mathrm{M}$ IAA (Anderson's medium-A) or $2.28 \mu \mathrm{M}$ zeatin (Anderson's medium-B) were used. The average $\mathrm{pH}$ was determined at 5.0.

\section{Rooting and acclimatization to ex vitro conditions}

To stimulate root growth, adventitious shoots measuring $6 \mathrm{~cm}$ in length were transferred individually onto Anderson's phytohormone-free medium (1980) supplemented with $3 \%$ sucrose and $0.7 \%$ agar with $\mathrm{pH}$ of 5.0. Plantlets with well-developed roots that had reached approximately $10 \mathrm{~cm}$ in height were transferred to plastic pots filled with sphagnum-peat and perlite mixture (3:1) for hardening and acclimatization, and they were transferred to the greenhouse for up-growth.

\section{Culture conditions}

Callus was induced from explants over a period of 12 weeks. Formed calluses were excised from explants, transferred onto fresh media and cultured for another 12 weeks. All calluses were cultured in dark at a temperature of $22 \pm 2^{\circ} \mathrm{C}$. To induce the formation and elongation of adventitious shoots, the cultures were kept under standard conditions of $22 \pm 2^{\circ} \mathrm{C}$ and a photoperiod of 16 hours of light and 8 hours of dark (light intensity $\sim 50 \mu \mathrm{mol} \mathrm{m}{ }^{-2} \mathrm{~s}^{-1}$ ) for 12 weeks.

\section{Morphological evaluation}

The cultured material was observed every seven days, and the final observations were performed at the end of week 24 for callus cultures and the end of week 12 for adventitious shoots cultures.

Callus size was evaluated on a scale of 0 to 6 , where $0=$ no callus, $1=$ callus diameter $<0.3 \mathrm{~cm}$, $2=$ callus diameter of $0.3-0.5 \mathrm{~cm}, 3=0.5-1 \mathrm{~cm}, 4=$ callus diameter of $1-1.5 \mathrm{~cm}, 5=$ callus diameter of $1.5-2 \mathrm{~cm}$, and $6=$ maximum callus diameter $>2 \mathrm{~cm}$.

The number of shoots per explant was observed in each medium, and shoot length was measured.

\section{Statistical analysis}

Each experimental treatment consisted of five series with ten replicates each. The collected data were subjected to an analysis of variance, and the results were verified statistically by Duncan's test.

\section{Results}

The effect of IAA and TDZ concentrations on callus and adventitious shoot formation

Callus and adventitious shoots were not formed on media supplemented with IAA alone or on the phytohormone-free medium. Callus formation on explants and shoot regeneration were significantly reduced $(p<0.05)$ on media supplemented with TDZ alone (Table 1). The average diameter of calluses induced on SE-L reached $0.43 \mathrm{~cm}$ (callus size -2 ) on the medium containing $5 \mu \mathrm{M} \mathrm{TDZ}$ alone and $0.48 \mathrm{~cm}$ (callus size -2 ) on the medium supplemented with $10 \mu \mathrm{M}$ TDZ alone. On SE-S explants, the average callus diameter was determined at $0.52 \mathrm{~cm}$ (callus size - 3) on the medium containing $5 \mu \mathrm{M} \mathrm{TDZ}$ alone and $0.64 \mathrm{~cm}$ (callus size -3 ) on the medium supplemented with $10 \mu \mathrm{M}$ TDZ alone. After 12 weeks of subculturing on BM containing 5 or $10 \mu \mathrm{M} \mathrm{TDZ}$, infrequent adventitious buds (1-3 buds per explant on average) were observed on $5-10 \%$ of calluses induced on explants (both leaf and stem) (Table 1). Callus proliferation and adventitious shoot formation were significantly higher $(\mathrm{p}<0.05)$ on media containing both TDZ and IAA, and no significant variations were noted between different concentrations of IAA (5-10 $\mu \mathrm{M})$. In all cases, the average diameter of calluses induced on explants was $1.63 \mathrm{~cm}$ (callus size -5), and

Table 1. Indirect regeneration of adventitious shoots from Ch. calyculata leaves and stems after exposure to different concentrations of TDZ and IAA in the basal medium (BM)

\begin{tabular}{|c|c|c|c|c|c|}
\hline \multirow{2}{*}{$\operatorname{TDZ}(\mu \mathrm{M})$} & \multirow{2}{*}{$\begin{array}{l}\text { IAA } \\
(\mu \mathrm{M})\end{array}$} & \multirow{2}{*}{$\begin{array}{l}\text { Percentage (\%) of SE-L } \\
\text { producing callus (A) }\end{array}$} & \multirow{2}{*}{$\begin{array}{l}\text { Percentage (\%) of SE-S } \\
\text { producing callus (B) }\end{array}$} & \multicolumn{2}{|c|}{ Percentage (\%) of callus regenerated shoots } \\
\hline & & & & Callus A & Callus B \\
\hline 0 & 0 & 0 & 0 & 0 & 0 \\
\hline 5 & 0 & $6.8 \pm 2.8 \mathrm{a}$ & $13.2 \pm 5.8 \mathrm{~b}$ & $5.8 \pm 3.4 \mathrm{a}$ & $7.8 \pm 2.6 \mathrm{ab}$ \\
\hline 0 & 5 & 0 & 0 & 0 & 0 \\
\hline 5 & 5 & $55 \pm 9.4 \mathrm{c}$ & $65 \pm 8.7 c$ & $75 \pm 7.9 c$ & $80 \pm 6.7 c$ \\
\hline 0 & 10 & 0 & 0 & 0 & 0 \\
\hline 5 & 10 & $59 \pm 10.4 \mathrm{c}$ & $69 \pm 3.2 c$ & $78.3 \pm 9.9 \mathrm{c}$ & $85.3 \pm 2.9 \mathrm{c}$ \\
\hline 10 & 0 & $7.2 \pm 4.4 \mathrm{a}$ & $16.8 \pm 6.8 \mathrm{~b}$ & $6.3 \pm 5.8 \mathrm{ab}$ & $10.3 \pm 2.8 \mathrm{ab}$ \\
\hline 10 & 5 & $87 \pm 16.8 \mathrm{~d}$ & $90 \pm 10.8 \mathrm{~d}$ & $95.7 \pm 4.8 \mathrm{~d}$ & $98.2 \pm 8.6 \mathrm{~d}$ \\
\hline 10 & 10 & $70 \pm 7.6 \mathrm{~cd}$ & $78 \pm 4.6 \mathrm{~cd}$ & $87.8 \pm 14.4 \mathrm{~cd}$ & $89.8 \pm 10.4 \mathrm{~cd}$ \\
\hline
\end{tabular}

The results are the means of five replicates with standard error $( \pm \mathrm{SE})$. The numbers followed by the same letter in each column are not significantly different $(p<0.05)$ 

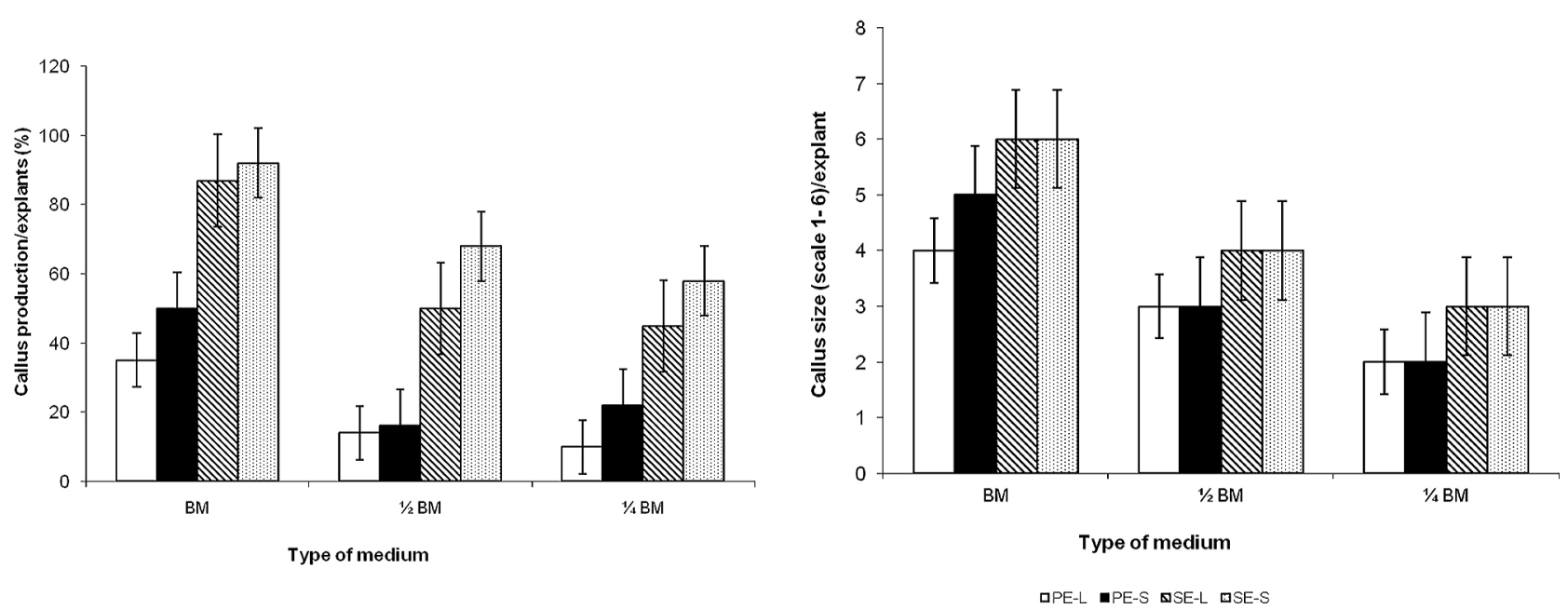

Fig. 1. The effect of mineral salt concentrations on callus induction (A) and development (B) in leatherleaf (Chamaedaphne calyculata)

All media were supplemented with $10 \mu \mathrm{M} \mathrm{TDZ}$ and $5 \mu \mathrm{M}$ IAA.

Observations were performed after 24 weeks of dark treatment. The results are the means of five replicates. Vertical bars represent standard error.

an average of 27 buds were formed per explant. The media supplemented with $10 \mu \mathrm{M} \mathrm{TDZ}$ and $5 \mu \mathrm{M}$ IAA were characterized by the highest percentage of callus-producing explants and the highest percentage of callus regenerated shoots (Table 1 ). For this reason, the above concentrations were used in subsequent experiments.

The effect of mineral salt concentrations on the induction and development of calluses and adventitious shoots

Visible changes were observed in explants after 24 weeks of dark treatment. Most explants swelled after four weeks of incubation on all tested media (with different concentrations of mineral salts, supplemented with $10 \mu \mathrm{M} \mathrm{TDZ}$ and $5 \mu \mathrm{M} \mathrm{IAA}$ ). The highest degree of swelling was noted on the BM medium, followed by $1 / 2 \mathrm{BM}$ and $1 / 4 \mathrm{BM}$. The following trend was observed in successive stages of culturing: the lower the concentrations of mineral salts in the tested media, the slower the growth of calluses in each stage, which resulted in less developed calluses (Fig. 1).

In primary explants cultured on the BM medium with $10 \mu \mathrm{M}$ TDZ and $5 \mu \mathrm{M}$ IAA, callus tissue was formed on $35 \%$ of leaf explants (PE-L) and $50 \%$ of stem explants (PE-S) in week 24. Calluses induced on PE-L were $1.1-1.5 \mathrm{~cm}$ in diameter (callus size 4 ), and calluses grown on PE-S were $1.6-2.0 \mathrm{~cm}$ in diameter (callus size - 5) (Fig. 1).

In secondary explants cultured on the BM medium with $10 \mu \mathrm{M}$ TDZ and $5 \mu \mathrm{M}$ IAA for 24 weeks, callus diameter exceeded $2.5 \mathrm{~cm}$ (callus size - 6) in $87 \%$ of leaf explants (SE-L) and in $92 \%$ of stem explants (SE-S).

In primary explants cultured on the $1 / 2 \mathrm{BM}$ medium with $10 \mu \mathrm{M}$ TDZ and $5 \mu \mathrm{M}$ IAA for 24 weeks, callus diameter reached $0.6-1.0 \mathrm{~cm}$ (callus size -3 ) in $14 \%$ of PE-L and in $16 \%$ of PE-S stem explants.
In secondary explants cultured on the $1 / 2 \mathrm{BM}$ medium with $10 \mu \mathrm{M}$ TDZ and $5 \mu \mathrm{M}$ IAA, callus diameter exceeded $1.5 \mathrm{~cm}$ (callus size - 4) in 50\% of SE-L and in $68 \%$ of SE-S stem explants.

In primary explants grown on the $1 / 4 \mathrm{BM}$ medium with $10 \mu \mathrm{M}$ TDZ and $5 \mu \mathrm{M}$ IAA and, callus clusters with a diameter of $0.3-0.5 \mathrm{~cm}$ (callus size -2 ) were reported in $10 \%$ of PE-L and in $22 \%$ of PE-S explants in week 12. In secondary explants cultured for 24 weeks on the $1 / 4 \mathrm{BM}$ medium with $10 \mu \mathrm{M}$ TDZ and $5 \mu \mathrm{M}$ IAA, callus tissue proliferated to $0.6-1.0 \mathrm{~cm}$ in diameter (callus size - 3) in $45 \%$ of SE-L and in $58 \%$ of SE-S explants.

There was no response to control media. When leaf or stem explants were cultured on a medium without salts or plant growth regulators, explants tended to turn brown, and they died within a short period of time (data not shown).

The percent range of callus regenerated shoots and the average number of shoots per explant varied significantly at different concentrations of mineral salts. The frequency of adventitious shoot proliferation and the number of shoots per explant decreased with a drop in mineral salt concentrations in the medium. Regardless of the explant's origin, intensive tissue proliferation and changes in color from bright yellow to green were noted in the first three weeks of culture on the BM medium with $10 \mu \mathrm{M} \mathrm{TDZ}$ and $5 \mu \mathrm{M}$ IAA (Fig. 2B).

After 12 weeks of subculturing on the BM medium with $10 \mu \mathrm{M} \mathrm{TDZ}$ and $5 \mu \mathrm{M}$ IAA, infrequent adventitious buds (1-3 buds per explant on average) were observed on $10-20 \%$ of calluses induced from primary explants (both leaf and stem) (Table 2A). Despite successive passages, a significant increase in the number of shoots was not observed, but callus tis- 
sue proliferation was noted. In week 12 of subculturing on the $1 / 2 \mathrm{BM}$ medium with $10 \mu \mathrm{M}$ TDZ and $5 \mu \mathrm{M}$ IAA, an average of $94 \%$ calluses grown from secondary explants (both leaf and stem) showed numerous adventitious shoots (25-35 shoots per explant on average) with a length of 0.7 to $1.0 \mathrm{~cm}$ (Fig. 2C; Table $2 \mathrm{~B}$ ). After the transfer of calluses from PE-L and PE-S onto the $1 / 2 \mathrm{BM}$ medium containing $10 \mu \mathrm{M}$ TDZ and $5 \mu \mathrm{M}$ IAA and the $1 / 4 \mathrm{BM}$ medium supplemented with $10 \mu \mathrm{M}$ TDZ and $5 \mu \mathrm{M}$ IAA, the emergence of adventitious shoots was not observed, and only gradual proliferation of callus tissue was noted (Tables $2 \mathrm{~B}$ and $2 \mathrm{C}$ ). Approximately $60 \%$ of calluses induced from secondary explants on media with reduced mineral salt content $(1 / 2 \mathrm{BM}$ medium with $10 \mu \mathrm{M}$ TDZ and $5 \mu \mathrm{M}$ IAA, and $1 / 4$ BM medium with $10 \mu \mathrm{M}$ TDZ and $5 \mu \mathrm{M}$ IAA) produced an organogenic response (Tables 2B and 2C). The resulting shoots were less numerous and shorter than those grown on the BM medium with $10 \mu \mathrm{M} \mathrm{TDZ}$ and $5 \mu \mathrm{M}$ IAA.

The effect of medium type on the elongation of adventitious shoots

The length of adventitious shoots formed on callus clumps derived solely from secondary explants (leaves and stems) was significantly (statistically) affected by the type of phytohormones added to the medium and, less significantly (non-statistically), by the type of the tested medium. In general, shoot elongation was inhibited by TDZ and stimulated by zeatin. Regardless of the type of the applied phytohormone, shoots grown on the basal medium were shorter than those cultured on Anderson's medium (1980). The average length of shoots cultured for 12 weeks on BM-A and Anderson's medium-A (ba-
Table 2. The effect of mineral salt concentrations on the induction and development of adventitious shoots from callus tissue in leatherleaf (Ch. calyculata) cultured for 12 weeks

\begin{tabular}{lrrr}
\hline $\begin{array}{c}\text { Callus } \\
\text { induced } \\
\text { on }\end{array}$ & $\begin{array}{c}\text { Percentage of } \\
\text { callus regenerated } \\
\text { shoots (\%) }\end{array}$ & $\begin{array}{c}\text { Mean number } \\
\text { of shoots per } \\
\text { explant }\end{array}$ & $\begin{array}{c}\text { Mean length } \\
\text { of adventitious } \\
\text { shoots }(\mathrm{cm})\end{array}$ \\
\hline \multicolumn{4}{c}{ A. BM medium } \\
\hline PE-L & $10 \pm 1.2 \mathrm{a}$ & $2 \pm 0.8 \mathrm{a}$ & $0.05 \pm 0 \mathrm{a}$ \\
PE-S & $20 \pm 2.3 \mathrm{~b}$ & $3 \pm 0.9 \mathrm{a}$ & $0.1 \pm 0.04 \mathrm{~b}$ \\
SE-L & $93 \pm 1.6 \mathrm{c}$ & $25 \pm 1.3 \mathrm{~b}$ & $0.8 \pm 0.06 \mathrm{c}$ \\
SE-S & $95 \pm 1.8 \mathrm{c}$ & $35 \pm 1.4 \mathrm{~b}$ & $1 \pm 0.07 \mathrm{c}$ \\
\hline \multicolumn{5}{c}{ B. $1 / 2 \mathrm{BM}$ medium } \\
\hline PE-L & $0 \pm 0.5 \mathrm{a}$ & $0 \pm 0.3 \mathrm{a}$ & $0 \pm 0.08 \mathrm{a}$ \\
PE-S & $0 \pm 1.0 \mathrm{a}$ & $0 \pm 0.4 \mathrm{a}$ & $0 \pm 0.09 \mathrm{a}$ \\
SE-L & $63 \pm 1.9 \mathrm{~b}$ & $7 \pm 0.8 \mathrm{~b}$ & $0.4 \pm 0.08 \mathrm{~b}$ \\
SE-S & $55 \pm 2.3 \mathrm{~b}$ & $10 \pm 0.9 \mathrm{~b}$ & $0.5 \pm 0.09 \mathrm{~b}$ \\
\hline \multicolumn{5}{c}{ C. $1 / 4 \mathrm{BM}$ medium } \\
\hline PE-L & $0 \pm 0.7 \mathrm{a}$ & $0 \pm 0.4 \mathrm{a}$ & $0 \pm 0.07 \mathrm{a}$ \\
PE-S & $0 \pm 0.6 \mathrm{a}$ & $0 \pm 0.3 \mathrm{a}$ & $0 \pm 0.06 \mathrm{a}$ \\
SE-L & $60 \pm 2.8 \mathrm{~b}$ & $5 \pm 1.2 \mathrm{~b}$ & $0.3 \pm 0.09 \mathrm{~b}$ \\
SE-S & $63 \pm 1.4 \mathrm{~b}$ & $8 \pm 0.8 \mathrm{~b}$ & $0.3 \pm 0.04 \mathrm{~b}$ \\
\hline
\end{tabular}

All media were supplemented with $10 \mu \mathrm{M}$ TDZ and $5 \mu \mathrm{M}$ IAA.

The results are the means of five replicates with standard error $( \pm \mathrm{SE})$. The numbers followed by the same letter in each column are not significantly different $(\mathrm{p}<0.05)$

sal medium and Anderson's medium (1980), both supplemented with $10 \mu \mathrm{M}$ TDZ and $5 \mu \mathrm{M}$ IAA), was determined at $0.5 \mathrm{~cm}$ and $1.0 \mathrm{~cm}$, respectively (Fig. $3)$. The shoots grown on BM-B and Anderson's medium-B (basal medium and Anderson's medium (1980), both supplemented with $2.28 \mu \mathrm{M}$ zeatin) reached the length of $3.0 \mathrm{~cm}$ and $6.0 \mathrm{~cm}$, respectively, after 12 weeks (Fig. 3). The origin of the callus ap-
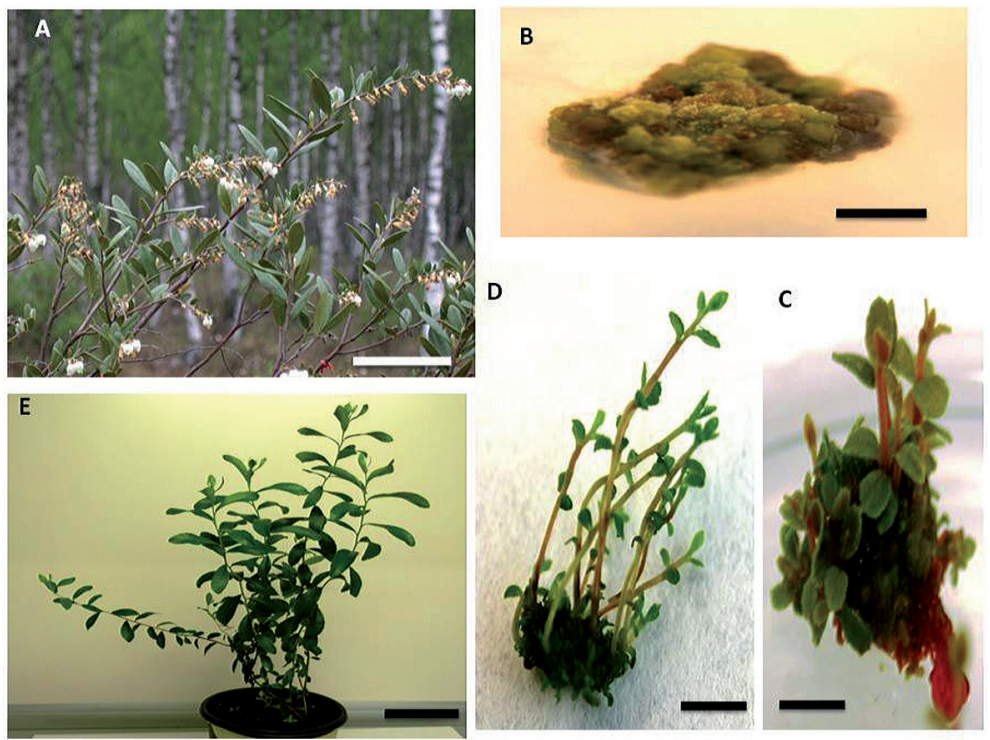

Fig. 2. A. Wild-grown Chamaedaphne calyculata (L.) Moench (scale bar $=200 \mathrm{~mm}$ ). B. Callus induced on SE-L (scale bar $=$ $2 \mathrm{~mm}$ ). C. Adventitious shoots formed after 24 weeks from callus (scale bar $=5 \mathrm{~mm}$ ) cultured on BM media supplemented with $10 \mu \mathrm{M}$ TDZ or $5 \mu \mathrm{M}$ IAA. D. Elongation of adventitious shoots on EM-D after 12 weeks (scale bar $=10$ $\mathrm{mm})$. E. Acclimatized young plant in a pot (scale bar $=50 \mathrm{~mm})$ 


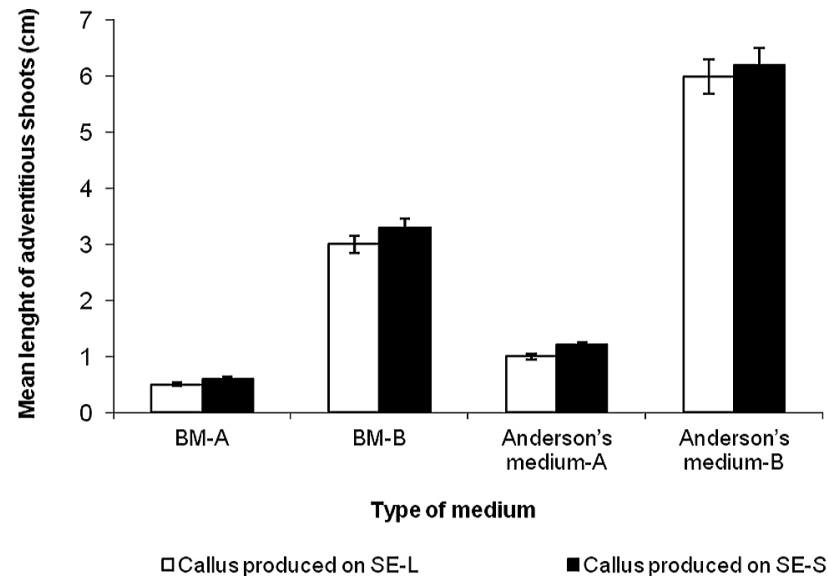

Fig. 3. The effect of medium type on the elongation of adventitious shoots derived from callus tissue grown on SE-L ( $\square$ ) and SE-S (ロ) explants in leatherleaf (Ch. calyculata)

BM - basal medium or Anderson's medium (1980) supplemented with

$10 \mu \mathrm{M}$ TDZ and $5 \mu \mathrm{M}$ IAA (variant A) or $2.28 \mu \mathrm{M}$ zeatin (variant B).

Observations were performed after 12 weeks of growth under photoperiod conditions. The results are the means of five replicates. Vertical bars represent standard error

plied in the culture had no significant effect on shoot elongation.

Rooting and acclimatization to ex vitro conditions

Adventitious roots were formed in $75 \%$ of shoot explants cultured for 10 weeks on Anderson's phytohormone-free (1980) medium. Rooting was accompanied by the elongation of shoots on rooting media. Approximately $65 \%$ of plantlets grew vigorously under greenhouse conditions two months after the transfer, and they showed no signs of water stress or morphological variation (Fig. 2E). The type of explant and the type of media used for indirect organogenesis or adventitious shoot elongation had no effect on the resulting percentage of rooting and surviving plantlets (data not shown).

\section{Discussion}

Adventitious shoot regeneration via direct and indirect organogenesis is common in in vitro cultures of heath plants, in particular members of the genera Vaccinium and Rhododendron. In many species, those processes contribute to higher proliferation rates than those yielded by shoot tip or axillary bud cultures. The relevant data are not available for $\mathrm{Ch}$. calyculata.

Huetteman and Preece (1993) reported that a range of tissues from both ex vitro and in vitro sources may be used with varying success in the micropropagation of woody plants. The regeneration of adventitious shoots in Ericaceae species has been induced from various tissues, including the ovaries (Tomsone and Gertnere 2003), stamens (Shevade and Preece 1993), stem segments (Meiners et al. 2007), shoot tips (Vejsadova 2008) and leaf explants (Tomsone and Gertnere 2003; Meiners et al. 2007). Leaf tissues and stem segments are the preferred sources of explants because they are readily available throughout the growing season (Tiwari and Chauhan 2006). Secondary explants (usually isolated from plantlets germinated in vitro) are also often used in organogenesis experiments because they do not require sterilization and are easier to culture than materials obtained ex vitro. In the presented experiment, leaves and stems from both ex vitro and in vitro sources were used as explants. In this study, secondary explants offered the most supportive environment for inducing calluses (Table 2, Fig. 1) and for inducing and elongating adventitious shoots (Table 2, Fig. 3). Similar results were reported by Gajdosova et al. (2006) who relied on adventitious organogenesis to scale up clonal propagation of selected Vaccinium genotypes with the use of leaf explants derived from in vitro grown plants. The direct regeneration of adventitious shoots was effective in the presence of intermediary callus.

In a study published as early as in 1957, Skoog and Miller pointed out that the stimulation of tissue growth for the formation of adventitious roots and shoots depends on the auxin to cytokinin ratio in the culture medium. A variety of cytokinins (dimethylallylaminopurine, zeatin, kinetin, 6-benzylaminopurine, thidiazuron) and auxins (2,4-dichlorophenoxyacetic acid, indole-3-acetic acid, naphthaleneacetic acid) have been examined to date, both individually and in combinations, to improve regeneration in various species of the family Ericaceae. The effect of cytokinin type on the morphogenetic response was discussed by Hruskoci and Read (1992, 1993) who observed both direct and indirect regeneration of adventitious shoots from the internodes of a blueberry hybrid (northern highbush blueberry $\mathrm{x}$ lowbush blueberry) treated with cytokinin, zeatin and thidiazuron, respectively.

In recent years, TDZ has been increasingly often used to induce the formation of adventitious shoots (Meiners et al. 2007). Little is known about the mechanism by which TDZ induces organogenesis and somatic embryogenesis in many plant species, but in the above processes, it has been found to act as a substitute for both auxin and cytokinin requirements (Debnath 2003; He at al. 2007). The dose of TDZ is critical in shoot organogenesis (Lu 1993). Although TDZ supports regeneration in selected Vaccinium (Cao and Hammerschlang 2000) and Rhododendron (Tomsone and Gertnere 2003; Tomsone et al. 2004) species as well as in Leucopogon verticillatus (Anthony et al. 2004), its effectiveness in regener- 
ating Ch. calyculata has not yet been demonstrated. According to several studies, auxins are required for the regeneration of adventitious shoots because TDZ and auxin combinations applied in the medium increase the number of responsive explants (Cuenca and Vieitez 1999; Singh et al. 2003; Meiners et al. 2007). This study demonstrated that TDZ induced explant swelling, callus formation and, in several cases, shoot differentiation. Those changes were not observed in controls or in media containing only IAA. TDZ concentrations and the presence of IAA greatly influence the frequency, growth and the number of formed calluses, buds and shoots, with $10 \mu \mathrm{M}$ TDZ and $5 \mu \mathrm{M}$ IAA being the most suitable range (Table 1 ). The above findings are consistent with the results noted by other authors (Cuenca and Vieitez 1999; Meiners et al. 2007).

Several factors are known to influence callus production and shoot organogenesis, in particular explant type, medium type, the presence of plant growth regulators (especially auxins) and the genotype (Brown and Thorpe 1986). Various types and concentrations of salts have been designed for use in tissue cultures. The most suitable medium that meets species-specific requirements has to be found. The Murashige and Skoog medium (1962) has been widely used for in vitro shoot proliferation of various plant species. According to McCown (2000), Ericaceae are intolerant of 6-benzylaminopurine or the Murashige and Skoog medium (1962), both of which stunt shoot growth. Low-salt media developed by Anderson (1980), Zimmerman and Broome (1980), and Lloyd and McCown (1980) have been successfully used for shoot establishment and proliferation in a wide range of ericaceous species, with some modifications of medium strength for selected species (McCown 2000; Tiwari and Chauhan 2006). In this study, the mineral salt content of culture media significantly influenced the induction and growth of the callus (Fig. 1) as well as the induction (Table 2) and elongation of adventitious shoots in Ch. calyculata (Fig. 3).

It is generally believed that cytokinins stimulate shoot proliferation and inhibit shoot elongation. Therefore, the inhibition of shoot elongation by TDZ may be consistent with its high cytokinin activity, and it should not be regarded as a toxic effect (Huetteman and Preece 1993). It was also observed that higher zeatin concentrations (above $2.28 \mu \mathrm{M}$ ) promoted callus formation (Gajdosova et al. 2006). Despite the above, the results of this experiment and other studies investigating heath plants suggest that low concentrations of cytokinins (in particular zeatin) are very effective in promoting shoot induction and shoot elongation (Tomsone and Gertnere 2003; Gajdosova et al. 2006). The inhibitory effect of TDZ on shoot elongation can be often minimized by transferring shoots to a medium containing zeatin (Deb- nath 2003; Meiners et al. 2007). In this study, the elongation of adventitious shoots was inhibited by TDZ and stimulated by zeatin regardless of the applied media (Fig. 3).

The efficient rooting of regenerated shoots and the survival of plantlets in soil are important final steps for successful micropropagation. Heath plant shoots obtained in vitro can be rooted easily in vitro using auxins (in particular indole-3-butyric acid) or ex vitro in a humidity chamber without any hormone treatment. The root formation percentage of in vitro shoots rooted ex vitro is often similar to that noted in in vitro rooting experiments. Thus, the in vitro rooting stage can be omitted, and in vitro shoots can be rooted directly in the greenhouse. Nevertheless, in vitro rooting offers a good opportunity for rooting cultivars that do not root easily under greenhouse conditions (Meiners et al. 2007). The experimental data pertaining to Ch. calyculata describe only the rooting of shoots derived from mature plants harvested from natural stands in the Drawa National Park. Malinowska et al. (2004) analyzed shoots cut perpendicularly to the shoot axis, with a $1 \mathrm{~cm}$ incision on the side, treated with a rooting agent and rooted in $100 \%$. The results of our previous studies indicate that leatherleaf is equally well rooted in phytohormone-free media and in media supplemented with auxins (data not shown). Ex vitro rooting was significantly less effective (unpublished data). For this reason, the rooting process in this experiment was carried out in vitro on phytohormone-free media. The reported results are consistent with the findings of other authors (Litwińczuk and Wadas 2008).

This study makes a pioneering attempt to analyze callogenesis and indirect organogenesis in Chamaedaphne calyculata (L) Moench. Indirect organogenesis (preceded by callus formation) creates a basis for investigating somatic embryogenesis that has been poorly researched in heath plants and remains unexplored in leatherleaf.

\section{References}

Anderson W.C. 1980. Tissue culture propagation of red and black raspberries, Rubus idaeus and R. occidentalis. ActaHorticulturae 112: 124-132.

Anthony J.M., Senarata T., Dixon K.W., Sivasithamparam K. 2004. Somatic embryogenesis for mass propagation of Ericaceae - a case study with Leucopogon verticillatus. Plant Cell, Tissue and Organ Culture 76: 137-146. http://dx.doi.org/10.1023/ B:TICU.0000007285.73884.fc

Brown D.C.W., Thorpe T.A. 1986. Plant regeneration by organogenesis. In: Cell culture and somatic cell genetics of plants. Vol. 3. Vasil, I.K.(ed.). Academic Press, Orlando, pp. 49-66. 
Cao X., Hammerschlang F.A. 2000. Improved shoot organogenesis from leaf explants of highbush blueberry. HortScience 35: 945-947.

Cuenca B., Vieitez A.M. 1999. Histological Study of in vitro development of adventitious buds on leaf explants of oriental beech (Fagus orientalis Lipsky). In Vitro Cellular \& Developmental Biology - Plant 35: 326-332. http://dx.doi.org/10.1007/s11627999-0043-8

Debnath S.C. 2003. Improved shoot organogenesis from hypocotyl segments of lingonberry (Vaccinium vitis-idaea L.). In Vitro Cellular \& Developmental Biology - Plant 39: 490-495. http://dx.doi. org/10.1079/IVP2003458

Gajdosova A., Ostrolucka M.G., Libiakova G., Ondruskova E., Simala D. 2006. Microclonal propagation of Vaccinium sp. and Rubus sp. and detection of genetic variability in culture in vitro. Journal of Fruit and Ornamental Plant Research 14: 103-119.

Gamborg O.L., Miller R.A., Ojima K. 1968 Nutrient requirements of suspension cultures of soybean root cells. Experimental Cell Research 50: 151-158. http://dx.doi.org/10.1016/00144827(68)90403-5

He S.-S., Liu Ch.-Z., Saxena P.-K. 2007. Plant regeneration of an endangered medicinal plant Hydrastis canadensis L. Scientia Horticulturae 113: 82-86. http://dx.doi.org/10.1016/j.scienta.2007.01.014

Hruskoci J.D., Read P.E. 1992. In vitro shoot regeneration from internode segments and internode-derived callus of blueberry (Vaccinium spp.). HortScience 27: 571.

Hruskoci J.D., Read P.E. 1993. In vitro shoot regeneration from internode segments and internode-derived callus of blueberry (Vaccinium spp.). Acta Horticulturae 346:127-132.

Huetteman C.A., Preece J.E. 1993. Thidiazuron: a potent cytokinin for woody plant tissue culture. Plant Cell Tissue and Organ Culture 33: 105-119. http://dx.doi.org/10.1007/BF01983223

Kruszelnicki J. 2001. Chamedafne północna (Chamaedaphne calyculata L. Moench). In: Polska czerwona księga roślin. Paprotniki i rośliny kwiatowe. Zarzycki K., Kaźmierczakowa R. (red.). Instytut Botaniki im. W. Szafera PAN, Kraków, pp. 283-285.

Litwińczuk W., Wadas M. 2008. Auxin-dependent development and habituation of highbush blueberry (Vaccinium covilleanum But. Et Pl.) 'Herbert' in vitro shoot cultures. Scientia Horticulturae 119: 41-48. http://dx.doi.org/10.1016/j.scienta.2008.07.007

Lloyd G., McCown B. 1980. Commercially-feasible micropropagation of Mountain laurel, Kalmia latifolia, by use of shoot tip culture. Combined Proceedings, International Plant Propagators' Society 30: 421-427.

Lu C.-Y. 1993. The use of thidiazuron in tissue culture. In Vitro Cellular \& Developmental Biology
- Plant 29: 92-96. http://dx.doi.org/10.1007/ BF02632259

Malinowska H., Janyszek A., Szczepaniak M. 2004. Propagation of leather leaf Chamaedaphne calyculata (L.) Moench from seeds and shoot cuttings. Dendrobiology 52: 33-37.

McCown B.H. 2000. Woody shrubs and trees. In: Plant Tissue Culture. Techniques and Experiments. Smith R.H. (ed.). Academic Press, USA, pp. 123-133.

Meiners J., Shwab M., Szankowski I. 2007. Efficient in vitro regeneration systems for Vaccinium species. Plant Cell, Tissue and Organ Culture 89: 169-176. http://dx.doi.org/10.1007/s1 1240-007-9230-7

Moerman D. 1998. Native American Ethnobotany. Timber Press, Oregon, pp. 135-145.

Murashige T., Skoog F. 1962. A revised medium for rapid growth and bio assays with tabasco tissue cultures. Physiologia Plantarum 15: 473-497. http://dx.doi.org/10.1111/j.1399-3054.1962. tb08052.x

Shelyuto V.L., Glyzin B.I. 1975. Guaiaverin from Chamaedaphne calyculata. - Vitebsk Medical Institute. Translated from Khimiya Prirodnkh Soedinenii 4: 515.

Shevade A., Preece J.E. 1993. In vitro shoot and floral organogenesis from stem explants from Rhododendron PJM group clone. Scientia Horticulturae 56: 163-170. http://dx.doi.org/10.1016/03044238(93)90017-K

Singh K.K., Kumar S., Rai L.K., Krishna A.P. 2003. Rhododendrons conservation in the Sikkim Himalaya. Current Science 85: 602-606.

Skoog F., Miller C.O. 1957. Chemical regulation of growth and organ formation in plant tissues cultured in vitro. In: The Biological Action of Growth Substances. Porter H.K. (ed.). Academic Press, New York pp. 118-131.

Tiwari O.N., Chauhan U.K. 2006. Rhododendron conservation in Sikkim Himalaya. Current Science 90: 532-541.

Tomsone S., Gertnere D. 2003. In vitro shoot regeneration from flower and leaf explants in Rhododendron. Biologia Plantarum 46: 463-465.

Tomsone S., Gertnere D., Novikova D. 2004. The influence of thidiazuron on shoot regeneration and proliferation of rhododendrons in vitro. Acta Universitatis Latviensis, Biology 676: 239-242. http://dx.doi.org/10.1023/A:1024363210872

Vejsadova H. 2008. Growth regulator effect on in vitro regeneration of rhododendron cultivars. HortScience (Prague) 35: 90-94.

Zimmerman R.H., Broome O.C. 1980. Blueberry micropropagation. - Proceedings of the Conference on Nursery Production of Fruit Plants through Tissue Culture USDA-SEA, Agricultural Research Results ARR-NE 11: 44-47. 